\title{
PENGEMBANGAN PERTANIAN ORGANIK TERINTEGRASI DI DESA ANTAPAN BATURITI TABANAN BALI
}

\author{
N.M.S. Sukmawati ${ }^{1}$, N.L. Kartini ${ }^{2}$, dan I.N. Sujana ${ }^{3}$
}

\begin{abstract}
ABSTRAK
Salah satu upaya untuk mengurangi ketergantungan petani pada pupuk dan pestisida anorganik adalah dengan memanfaatkan pupuk organik dan biopestisida. Selain menyuburkan tanaman, pupuk organik juga dapat mengurangi biaya produksi dan menjaga kelestarian lingkungan. Pengembangan pertanian terintegrasi yang didukung oleh teknologi fermentasi adalah salah satu cara yang sangat efektif untuk diterapkan di masyarakat. Sistem ini sering disebut sistem pertanian tanpa limbah karena limbah tanaman diolah untuk pakan ternak dan cadangan pakan pada musim kemarau dan limbah ternak (faeces, urine) diolah menjadi pupuk organik, bio urine, bio pestisida dan bio gas. Metode yang digunakan dalam kegiatan ini adalah melalui penyuluhan, pelatihan, pendampingan dan pembuatan demo plot aplikasi pupuk organik pada tanaman buncis $(0,5,10,15$ dan 20 ton/ha). Biopestisida digunakan adalah biourine sapi sebanyak $5 \%$ dengan cara disemprotkan pada daun. Dari hasil demplot menunjukkan bahwa produksi polong pada pemberian pupuk 5 ton/ha hampir sama dengan 20 ton/ha, sementara yang 10 dan 15 ton/ha produksinya lebih rendah dibandingkan 5 ton/ha dan yang tanpa pupuk organik produksinya paling rendah. Dari hasil demplot ini dapat disimpulkan bahwa penggunaan pupuk organik padat pada tanaman buncis cukup 5 ton/ha $\left(0,5 \mathrm{~kg} / \mathrm{m}^{2}\right)$.
\end{abstract}

Kata Kunci : pertanian organik, integrasi, desa Antapan

\begin{abstract}
One of the efforts to reduce farmers dependence on inorganic fertilizers and pesticides is by utilizing organic fertilizer and biopesticide. In addition to fertilize crops, organic fertilizers can also reduce production costs and maintain environmental sustainability. Integrated agricultural development supported by fermentation technology is one of a very effective way to be applied in the community. This system is often called a farm system without waste because plant waste processed for animal feed and backup feed during the dry season and livestock wastes (faeces, urine) processed into organic fertilizers, bio pesticides, bio urine and bio gas. The methods used in this activity is extension, training, monitoring and plots demonstration (demplot) of application organic fertilizer on beans crop $(0,5,10,15$ and 20 tons/ha). The pesticide used was beef biourine as much as $5 \%$ sprayed on the leaves. Results of the demplot showed that the pods production on organic fertilizer 5 tonnes/ha are almost equal to 20 tons/ha, while the 10 and 15 tons/ha were lower than 5 tons/ha and the least production was on beans without fertiliser. Based on the results, it can be concluded that the aplication of organic fertilizers on beans crop is quite 5 tons $/ \mathrm{ha}\left(0.5 \mathrm{~kg} / \mathrm{m}^{2}\right)$.
\end{abstract}

Keywords : organic farming, integration, Antapan village

${ }^{1}$ Staf Pengajar Fakultas Peternakan Universitas Udayana, suci_unud@yahoo.com

${ }^{2}$ Staf Pengajar Fakultas Pertanian Universitas Udayana

${ }^{3}$ Staf Pengajar Universitas Dwijendra 


\section{PENDAHULUAN}

Desa Antapan merupakan sebuah desa yang mata pencaharian penduduknya sebagian besar (61\%) sebagai petani tanaman holtikultura. Sistem pertanian sudah dilaksanakan secara intensif, namun hal ini memberikan dampak negatif terhadap lingkungan dan kesehatan manusia. Kegiatan usaha tani yang intensif tersebut telah mendorong pemakaian pupuk anorganik terus meningkat demikian juga pestisida. Penggunaan pupuk anorganik dan pestisida secara berlebihan akan menimbulkan pencemaran lingkungan dan berdampak negatif terhadap tanah, organisme yang hidup di dalam tanah, dan manusia yang mengkonsumsi produk holtikultura tersebut.

Alternatif pemecahan yang dapat dilakukan untuk mengurangi ketergantungan petani pada pupuk dan pestisida anorganik ialah dengan memanfaatkan pupuk organik dan biopestisida yang dikembangkan melalui sistem pertanian terintegrasi yang didukung oleh teknologi fermentasi. Pupuk organik memiliki kelebihan diantaranya bahan organik yang terkandung dalam pupuk tersebut mampu memperbaiki sifat fisik, kimia dan biologi tanah. Selain itu juga menambah kesuburan tanah, meningkatkan aktivitas jasad renik dan menahan air dalam tanah. Meskipun demikian pupuk organik juga memiliki kekurangan yakni kandungan hara makro dan mikronya yang relatif rendah, sehingga aplikasinya diperlukan dalam jumlah banyak (Rachmadani dkk, 2014). Sebagai upaya untuk melengkapi kekurangan tersebut maka harus dikombinasikan dengan penggunaan urine sapi (biourine). Menurut Soenarya (1988), selain mengandung unsur hara makro dan mikro, urine sapi juga mengandung hormon pertumbuhan.

Untuk mengetahui hasil dari penerapan pupuk organik ini maka dilakukan uji coba berupa demo plot pada salah satu jenis sayuran, yaitu tanaman buncis. Tanaman ini umurnya relatif pendek (umur 5 minggu sudah mulai berbunga) serta tahan terhadap serangan hama dan penyakit. Uji coba ini dilakukan dengan tujuan untuk memberi gambaran kepada masyarakat tentang penggunaan pupuk organik pada tanaman buncis serta dosis yang tepat.

\section{METODE PELAKSANAAN}

Pengembangan pertanian organik terintegrasi melalui program Ipteks bagi Wilayah (IbW) di desa Bangli dan Antapan, Baturiti, Tabanan dilaksanakan mulai bulan Mei sampai Oktober 2017. Alih teknologi tepat guna kepada masyarakat dilaksanakan melalui kegiatan sosialisasi, penyuluhan dan pelatihan pembuatan pupuk organik padat dan cair serta biopestisida sebagai pendukung program pertanian organik, serta kegiatan pendampingan. Ipteks yang diterapkan dalam pembuatan pupuk organik adalah teknologi fermentasi dengan fermentor hasil turunan EM4 dicampur dengan mikroorganisme lokal (MOL) dari limbah sayur dan kotoran ternak. Agar pemahaman masyarakat meningkat, kegiatan penyuluhan dilanjutkan dengan pembuatan demoplot pupuk organik padat dan cair serta biopestisida yang selanjutnya diaplikasikan pada tanaman sayuran.

\section{HASIL DAN PEMBAHASAN}

Pengembangan pertanian organik dengan sistem integrasi di Desa Antapan dilaksanakan secara bertahap, mulai dari sosalisasi, penyuluhan/pelatihan pembuatan pupuk organik padat dan cair dari kotoran sapi, pembuatan instalasi biogas, pembuatan embung membran sebagai tempat penampungan air untuk menyiram tanaman, dan pembuatan demplot sayuran organik. Penyuluhan dan pelatihan pengolahan kotoran sapi menjadi pupuk organik padat dan cair dilaksanakan di kandang milik kelompok ternak Setia Makmur, Br Mayungan Anyar, Desa Antapan, Baturiti, Tabanan.

\section{6 | BULETIN UDAYANA MENGABDI}


Untuk mendukung program pertanian organik terutama untuk irigasi di desa Antapan, dibangun beberapa tempat penyimpanan air yang disebut embung membran. Embung ini dibuat karena Desa Antapan mengalami kesulitan air terutama untuk menyiram tanaman holtikultura yang menjadi mata pencaharian di desa ini. Embung sistem geomembran yang didukung oleh teknologi pompa hidran (ram pump) untuk menaikkan air adalah salah satu upaya yang relatif lebih murah untuk menyediakan air dibandingkan dengan sistem beton dan pompa listrik. Embung ini dibuat seperti kolam ikan yang dilapisi terpal plastik sebagai penahan air. Pembagian air untuk embung ini dikelola oleh kelompok yang berjumlah 20 orang. Dengan adanya embung ini masyarakat sangat terbantu, dimana sebelumnya lahan di daerah ini banyak yang terbengkalai karena tidak ada air.

Selain pupuk padat dan cair, masih ada jenis pupuk lain yang tidak kalah kualitasnya yaitu limbah biogas yang disebut "slury". Sebagai sarana pendukung dari produk ini maka pada program ini dibangun sebuah instalasi biogas. Slury yang dihasilkan akan digunakan sebagai media untuk pembibitan sayuran. Beberapa dokumentasi kegiatan ditampilkan pada Gambar 3.1.

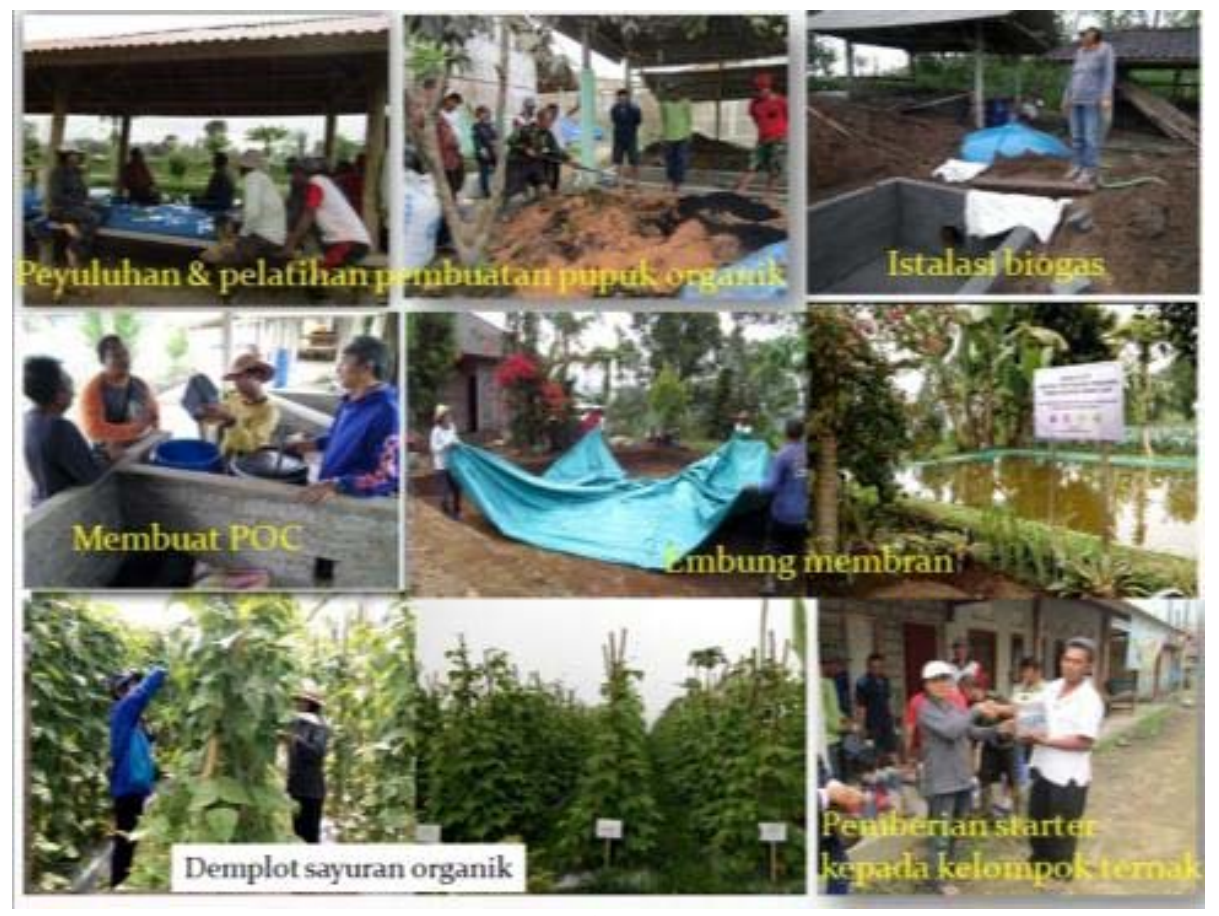

Gambar 3.1 Dokumentasi Kegiatan

Hasil demplot sayuran organik (kacang buncis) menunjukkan bahwa pada awal pertumbuhannya, tanaman buncis yang diberi pupuk organik memiliki pertumbuhan yang lebih lambat dibandingkan dengan tanpa pupuk. Setelah umur 4 minggu mulai ada perubahan, dimana buncis yang mendapat pupuk organik pertumbuhan vegetatifnya jauh lebih baik (daunnya lebih lebat, lebih lebar dan lebih hijau). Namun tanaman buncis yang diberi dosis 20 ton/ha pertumbuhannya hampir sama dengan tanpa pupuk, tetapi daunnya lebih hijau. Pemberian pupuk organik sebanyak 5 ton/ha pertumbuhannya sedikit lebih baik dibanding tanpa pupuk, sementara yang 10 dan 15 ton/ha pertumbuhannya terbaik dan sulit dibedakan secara visual. Tanaman yang mendapat pupuk organik 5-15 ton/ha kelihatan lebih hijau dan rimbun karena memiliki percabangan yang lebih banyak. Hal ini mencerminkan bahwa pada awal pertumbuhannya, tanaman belum bisa memanfaatkan pupuk organik padat secara maksimal karena belum terurai secara sempurna sehingga perlu ditambahkan pupuk cair. Kurang baiknya pertumbuhan pada perlakuan 20 ton/ha menunjukkan bahwa pada dosis tersebut kurang efektif dan berlebihan. Pupuk organik yang berlebihan menyebabkan air 
tanah pada kapasitas lapang yang seharusnya tersedia bagi tanaman ditarik sehingga tanaman kekurangan air.

Pertumbuhan generatif (pertumbuhan bunga) sudah mulai nampak pada umur 5 minggu, kecuali pada pemberian pupuk 20 ton/ha. Bunga tumbuh lebih cepat pada perlakuan tanpa pupuk dan memiliki tangkai bunga yang lebih pendek dibandingkan dengan perlakuan yang diberi pupuk organik. Pada umur 6 minggu tanaman buncis sudah mulai berbuah. Buah tertua nampak pada perlakuan tanpa pupuk. Hal ini disebabkan oleh kandungan hara terutama $\mathrm{N}$ pada tanah kurang sehingga tanaman cenderung lebih cepat berbunga. Produksi buah pada pemberian pupuk 5 ton/ha hampir sama dengan 20 ton/ha, sementara yang 10 dan 15 ton/ha produksinya lebih rendah dibandingkan 5 ton/ha dan yang tanpa pupuk organik produksinya paling rendah. Panjang polong pada perlakuan yang mendapat pupuk organik sedikit lebih panjang dibandingkan dengan tanpa pupuk.

\section{KESIMPULAN DAN SARAN}

Dari hasil kegiatan ini dapat disimpulkan bahwa pengembangan pertanian organik dengan sistem integrasi sangat efektif karena dapat menjaga kelestarian lingkungan dan mengurangi biaya produksi. Aplikasi pupuk organik padat sebagai pupuk dasar pada tanaman buncis cukup pada dosis 5 ton/ha.

Dari kesimpulan ini disarankan kepada petani/peternak untuk menerapkan pertanian organik secara terintegrasi karena dapat mengurangi biaya produksi serta ramah lingkungan. Penggunaan pupuk organik padat pada tanaman buncis cukup 5 ton/ha.

\section{UCAPAN TERIMAKASIH}

Penulis mengucapkan terima kasih kepada Direktorat Penelitian dan Pengabdian kepada Masyarakat, Dirjen DIKTI melalui Lembaga Penelitian dan Pengabdian masyarakat Unud, dan Pemda Kabupaten Tabanan atas dana yang diberikan sehingga pengabdian masyarakat berjalan dengan baik. Terima kasih juga penulis sampaikan kepada Bapak I Wayan Widana dan tim PKW atas semua bantuan dan dukungannya selama di lapangan.

\section{DAFTAR PUSTAKA}

Cahyono (2003). Kacang Buncis Teknik Budidaya dan Analisis Usaha Tani. Kanisius. Yogyakarta.

Cahyono, B. (2007). Rahasia Budidaya Buncis. Pustaka Mina. Jakarta.

Rachmadani, N. W., Koesriharti, dan Mudji Santoso (2014), Pengaruh Pupuk Organik dan Pupuk Anorganik Terhadap Pertumbuhan dan Hasil Tanaman Buncis Tegak (Phaseolus vulgaris L.), Jurnal Produksi Tanaman 2(6): 443-452

Suprijadi, G., N. Tjarya dan Soenaryo. 1988. Pengamatan Kualitatif Auksin, Kinetin dan Giberelin Pada Urin Sapi dan Domba. J. Warta.7 (6) : $24-28$ 